\title{
Isolation and characterisation of a single-stranded DNA virus infecting the marine planktonic diatom Chaetoceros tenuissimus
}

\author{
Yuji Tomaru ${ }^{1, *}$, Yoko Shirai $^{1}$, Kensuke Toyoda ${ }^{1,2}$, Keizo Nagasaki $^{1}$ \\ ${ }^{1}$ National Research Institute of Fisheries and Environment of Inland Sea, Fisheries Research Agency, 2-17-5 Maruishi, \\ Hatsukaichi, Hiroshima 739-0452, Japan \\ ${ }^{2}$ Present address: Department of Botany, Keio University, 4-1-1 Hiyoshi, Kohoku-ku, Yokohama, Kanagawa 223-8521, Japan
}

\begin{abstract}
Since the discovery of a single-stranded RNA virus infectious to Rhizosolenia setigera (Bacillariophyceae), several novel diatom-infecting viruses have been isolated and examined as a potential mortality source for diatom populations. Here, we report the isolation and characterisation of a new single-stranded DNA (ssDNA) virus (CtenDNAV) that causes lysis of the cosmopolitan diatom species Chaetoceros tenuissimus (Meunier). The virion is $37 \mathrm{~nm}$ in diameter and accumulates in the nucleus of host cells. CtenDNAV has a closed circular ssDNA genome (5639 nt), which includes a partially double-stranded region (875 bp) and at least 3 major open reading frames (ORFs). One ORF is similar to putative replicase-related proteins of the previously reported ssDNA diatom viruses, CsalDNAV and CdebDNAV. On the basis of the genome structure and host range, CtenDNAV is considered to belong to the new genus Bacilladnavirus. CtenDNAV is the second C. tenuissimus virus; the first was the single-stranded RNA virus CtenRNAV. Data from the present study suggest that the C. tenuissimus natural population is affected by at least 2 viruses differing in genome type.
\end{abstract}

KEY WORDS: Bacilladnavirus $\cdot$ Chaetoceros $\cdot$ Diatom $\cdot$ ssDNA $\cdot$ Virus $\cdot$ Rod-shaped particle

\section{INTRODUCTION}

No diatom-infecting viruses were identified in the 20th century. In 2004, the first diatom virus RsetRNAV (previously designated as RsRNAV) was isolated. Since then, at least 8 different diatom viruses have been isolated and characterised to different degrees. Some of them have been grouped into 1 of 2 newly proposed virus genera, Bacillarnavirus or Bacilladnavirus, the classifications of which have been accepted by the International Committee on Taxonomy of Viruses (http:// talk.ictvonline.org/). The genus Bacillarnavirus includes the single-stranded RNA (ssRNA) diatom viruses RsetRNAV (Nagasaki et al. 2004), CtenRNAV (Shirai et al. 2008) and CsfrRNAV (Tomaru et al. 2009b) which are infectious to Rhizosolenia setigera, Chaetoceros tenuissimus and Chaetoceros socialis $\mathrm{f}$. radians, respectively. The genus Bacilladnavirus includes a single-stranded DNA (ssDNA) diatom virus
CsalDNAV that is infectious to Chaetoceros salsugineum (Nagasaki et al. 2005). CdebDNAV, which infects Chaetoceros debilis, is also a ssDNA virus; however, the complete genome sequence and structure of this virus have not been completely identified (Tomaru et al. 2008). Two other diatom viruses, CspNIV and CwNIV, infect Chaetoceros cf. gracilis (Bettarel et al. 2005) and Chaetoceros cf. wighamii (Eissler et al. 2009), respectively, but their nucleic acid type is still unknown. All of these diatom viruses are 22 to $38 \mathrm{~nm}$ in diameter and specifically lyse their respective host diatom. Although knowledge of diatom viruses has gradually accumulated, multiple virus species sharing the same host diatom species have not been reported.

The virus that previously has been reported to infect Chaetoceros tenuissimus is a ssRNA virus (Shirai et al. 2008). The virus infecting $C$. tenuissimus, which we describe in the present paper, has a closed circular ssDNA genome and is supposed to be a member of the 
Bacilladnavirus. This is the first report of 2 viruses with different genome types (ssRNA and ssDNA) that share the same diatom host.

\section{MATERIALS AND METHODS}

Algal cultures and growth conditions. The axenic clonal algal strains used for virus isolation in the present study were Chaetoceros tenuissimus (Meunier) Strains 2-10 (Shirai et al. 2008), 2-6 and AG07-C03. Strain 2-10, previously used for isolation of CtenRNAV, was isolated from Maiko, Harima-Nada, Seto Inland Sea, Japan, on 10 August 2002 (Shirai et al. 2008). The 2-6 and AG07-C03 strains were isolated from surface water in Hiroshima Bay, Japan, on 9 July 2002 and surface water in Ago Bay, Japan, on 4 July 2007, respectively. Algal cultures were grown in modified SWM3 medium enriched with $2 \mathrm{nM} \mathrm{Na}_{2} \mathrm{SeO}_{3}$ (Chen et al. 1969, Itoh \& Imai 1987) under a 12 h light:12 h dark cycle of ca. 110 to $150 \mu \mathrm{mol}$ photons $\mathrm{m}^{-2} \mathrm{~s}^{-1}$ using cool white fluorescent illumination at $15^{\circ} \mathrm{C}$.

Virus isolation. Water samples $(0 \mathrm{~m}$ and $0.2 \mathrm{~m}$ above the bottom [B-0.2 m]) and sediment samples (0 to $3 \mathrm{~cm}$ depth for Ariake Sound and 0 to $1 \mathrm{~cm}$ depth for Hiroshima Bay) were collected from the mouth of the Shiotsuka River in Ariake Sound and from Itsukaichi Fishing Port in Hiroshima Bay, Japan, from 26 April 2005 through 15 October 2007. The water samples were filtered through $0.2 \mu \mathrm{m}$ Dismic-25cs filters (Advantec) to remove eukaryotic microorganisms and most bacteria. The sediment sample (12 g) was shaken
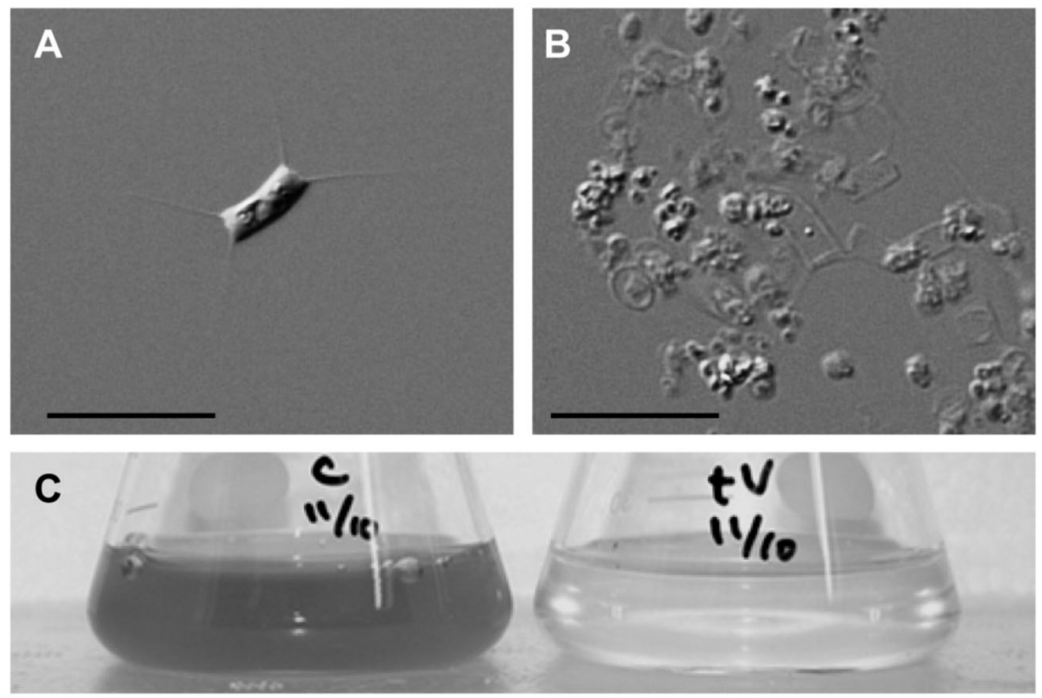

Fig. 1. Chaetoceros tenuissimus. (A) Optical micrograph of intact cells. (B) Optical micrograph of CtenDNAV-infected cells at $48 \mathrm{~h}$ post-inoculation (pi). Bars indicate $20 \mu \mathrm{m}$. (C) C. tenuissimus cultures: control (left) and CtenDNAV added (right), $8 \mathrm{~d}$ pi with $12 \mathrm{ml}$ of medium (400 rpm at room temperature for $30 \mathrm{~min}$ ) and centrifuged at $860 \times g$ at $4^{\circ} \mathrm{C}$ for $10 \mathrm{~min}$. The supernatants were sequentially passed through GF/F filters (Whatman) and $0.2 \mu \mathrm{m}$ Dismic-25cs filters (Advantec). Aliquots $(0.2 \mathrm{ml})$ of the filtrates obtained from the water and sediment samples were inoculated into exponentially growing Chaetoceros tenuissimus cultures $(0.8 \mathrm{ml})$, followed by incubation at $15^{\circ} \mathrm{C}$ using the light:dark cycle conditions described above. Algal cultures inoculated with SWM3 served as controls.

From the Chaetoceros tenuissimus cultures that showed an apparent crash after inoculation of the filtrates (e.g. Fig. 1), the responsible pathogens were cloned through 2 extinction dilution cycles (Suttle 1993, Tomaru et al. 2004). Bacterial contamination was removed from each lysate in the highest dilution well of the second assay by filtration through a $0.1 \mu \mathrm{m}$ polycarbonate membrane filter (Nuclepore) and was transferred to another exponentially growing host culture. To check for bacterial contamination, each lysate was observed using epifluorescence microscopy after staining with SYBR-Gold. Briefly, the lysate was fixed with glutaraldehyde at a final concentration of $1 \%$, and SYBR-Gold (Molecular Probes) was added to each fixed sample at a final concentration of $1.0 \times 10^{-4}$ dilution of the commercial stock. The stained samples were filtered onto $0.2 \mu \mathrm{m}$ pore size polycarbonate membrane filters (Nuclepore); then, the filters were mounted on a glass slide with a drop of low-fluorescence immersion oil and covered with another drop of immersion oil and a cover slip. The slides were viewed at a magnification of $\times 1000$ with an Olympus BX50 epifluorescence microscope. The resultant axenic lysate was referred to as a clonal virus suspension, and 8 virus clones were established (Table 1).

Host range. The intra-species host specificity of the 8 virus clones isolated in the present study and 1 other virus clone (CtenRNAV01; Shirai et al. 2008) was tested by adding $5 \%(\mathrm{v} / \mathrm{v})$ aliquots of fresh lysate passed through a $0.2 \mu \mathrm{m}$ polycarbonate membrane filter (Nuclepore) to duplicate cultures of the 14 exponentially growing Chaetoceros tenuissimus clonal strains (Table 2). The C. tenuissimus strains AR07-C01, -C02, -C03,-C04,-C05, -C06,-C07,-C08,-C09, $-\mathrm{C} 10$ and $-\mathrm{C} 12$ were isolated from the water samples collected in Ariake Sound, Kyushu, Japan, in September 2007. They were cultured under the conditions given above at $15^{\circ} \mathrm{C}$. Inter-species host specificity for the virus CtenDNAV06 was tested by adding $5 \%(\mathrm{v} / \mathrm{v})$ 
Table 1. Viruses infecting Chaetoceros tenuissimus that were isolated in the present study. B- $0.2 \mathrm{~m}$ : at $0.2 \mathrm{~m}$ above the bottom

\begin{tabular}{|lllll|}
\hline Virus isolate & Date & Location & Sample & Host strain code \\
\hline CtenV02 & 19 Apr 2006 & Hiroshima Bay & Sediment & C. tenuissimus 2-10 \\
CtenV03 & 12 May 2006 & Hiroshima Bay & Water (surface) & C. tenuissimus 2-10 \\
CtenV04 & 12 May 2006 & Hiroshima Bay & Sediment & C. tenuissimus 2-10 \\
CtenV05 & 19 Apr 2006 & Hiroshima Bay & Water (B-0.2 m) & C. tenuissimus 2-10 \\
CtenDNAV06 & 26 Apr 2005 & Ariake Sound & Sediment & C. tenuissimus 2-6 \\
CtenV07 & 15 Oct 2007 & Hiroshima Bay & Sediment & C. tenuissimus 2-6 \\
CtenV08 & 15 Oct 2007 & Hiroshima Bay & Water (B-0.2 m) & C. tenuissimus 2-6 \\
CtenV09 & 15 Oct 2007 & Hiroshima Bay & Sediment & C. tenuissimus AG07-C03 \\
\hline
\end{tabular}

Table 2. Chaetoceros tenuissimus. Viral susceptibility of 14 C. tenuissimus strains against 9 virus clones. + +: complete lysis; +: partial lysis; -: not lysed

\begin{tabular}{|c|c|c|c|c|c|c|c|c|c|}
\hline \multirow{2}{*}{$\begin{array}{l}\text { C. tenuissimus } \\
\text { strain code }\end{array}$} & \multirow[b]{2}{*}{ CtenRNAV01 } & \multirow[b]{2}{*}{ CtenV02 } & \multirow[b]{2}{*}{ CtenV03 } & \multirow{2}{*}{ CtenV04 } & \multirow{2}{*}{$\begin{array}{l}\text { us clones } \\
\text { CtenV05 }\end{array}$} & \multirow[b]{2}{*}{ CtenDNAV06 } & \multirow[b]{2}{*}{ CtenV07 } & \multirow[b]{2}{*}{ CtenV08 } & \multirow[b]{2}{*}{ CtenV09 } \\
\hline & & & & & & & & & \\
\hline $2-10$ & ++ & ++ & ++ & ++ & ++ & ++ & ++ & ++ & ++ \\
\hline $2-6$ & - & - & - & - & - & ++ & ++ & ++ & ++ \\
\hline AG07-C03 & - & - & - & - & - & - & ++ & - & ++ \\
\hline AR07-C01 & ++ & ++ & ++ & ++ & ++ & ++ & ++ & ++ & + \\
\hline AR07-C02 & - & - & - & - & - & ++ & - & - & + \\
\hline AR07-C03 & - & - & - & - & - & ++ & - & - & + \\
\hline AR07-C04 & - & - & - & - & - & ++ & - & - & + \\
\hline AR07-C05 & - & - & - & - & - & ++ & - & - & + \\
\hline AR07-C06 & - & - & - & - & - & ++ & - & - & + \\
\hline AR07-C07 & - & - & - & - & - & - & - & - & + \\
\hline AR07-C08 & - & - & - & - & - & - & - & - & + \\
\hline AR07-C09 & - & - & - & - & - & - & - & - & + \\
\hline AR07-C10 & - & - & - & - & - & - & - & - & + \\
\hline AR07-C12 & - & - & - & - & - & ++ & - & - & + \\
\hline
\end{tabular}

aliquots of fresh lysate passed through a $0.2 \mu \mathrm{m}$ polycarbonate membrane filter (Nuclepore) into duplicate cultures of the following 28 exponentially growing clonal algal strains that belong to the families Bacillariophyceae, Cryptophyceae, Dinophyceae, Eustigmatophyceae and Raphidophyceae, shown in Table 3.

They were cultured under the conditions given above at either 15 or $20^{\circ} \mathrm{C}$. Growth, cell condition and evidence of lysis in each algal culture were monitored by optical microscopy and compared to control cultures inoculated with SWM3 medium. Algal lysis was scored when an aggregation of lysed cells was observed on the bottom of culture vessels. Cultures apparently not lysed at $14 \mathrm{~d}$ post-inoculation (pi) were scored as unsuitable hosts for the viral pathogen.

Virus purification. A $450 \mathrm{ml}$ exponentially growing Chaetoceros tenuissimus 2-6 culture was inoculated with $5 \mathrm{ml}$ of CtenDNAV06 suspension and lysed. The lysate was passed through $0.4 \mu \mathrm{m}$ polycarbonate membrane filters (Nuclepore) to remove cellular debris. Polyethylene glycol 6000 (Wako Pure Chemical Industries) was added to the filtrate to a final concentration of $10 \%(\mathrm{w} / \mathrm{v})$, and the suspension was stored at $4{ }^{\circ} \mathrm{C}$ in the dark overnight. After centrifugation at $57000 \times g$ at $4^{\circ} \mathrm{C}$ for $1.5 \mathrm{~h}$, the pellet was washed with $10 \mathrm{mM}$ phosphate buffer ( $\mathrm{pH} 7.2$ ) and added to an equal volume of chloroform. After vigorous vortexing the suspension was centrifuged at $2200 \times g$ for $20 \mathrm{~min}$ at $4^{\circ} \mathrm{C}$ to remove the chloroform. The water phase was pipetted off and centrifuged at $217000 \times g$ for $4 \mathrm{~h}$ at $4^{\circ} \mathrm{C}$ to collect the virus particles. The resultant viral pellets were used for viral protein and genome analysis.

Viral proteins. The virus particles were resuspended in $600 \mu \mathrm{l}$ of ultrapure water. Aliquots $(5 \mu \mathrm{l})$ of the suspension were mixed with $4 \mathrm{vol}$ of denaturing sample buffer (62.5 mM Tris-HCl, $5 \%$ 2-mercaptoethanol, $2 \%$ sodium dodecyl sulfate [SDS], 20\% glycerol and $0.005 \%$ bromophenol blue) and boiled for $5 \mathrm{~min}$. The proteins were then separated using SDS-polyacrylamide gel electrophoresis $(80 \times 40 \times 1 \mathrm{~mm}, 12.5 \%$ polyacrylamide, 150 V) using the XV Pantera System (DRC). Proteins were visualised using Coomassie brilliant blue stain. Protein molecular mass standards (BioRad) ranging from 10 to $250 \mathrm{kDa}$ were used for size calibration.

Transmission electron microscopy. An exponentially growing culture of Chaetoceros tenuissimus 2-6 was inoculated with CtenDNAV06 suspension $(9.7 \%$ 
Table 3. Infection specificities of CtenDNAV06 against 28 strains of marine phytoplankton. -: not lysed; +: lysed

\begin{tabular}{|c|c|c|c|c|}
\hline Family & Species & Strain code & $\begin{array}{c}\text { Temperature } \\
\left({ }^{\circ} \mathrm{C}\right)\end{array}$ & $\begin{array}{c}\text { Strains lysed by } \\
\text { CtenDNAV06 }\end{array}$ \\
\hline \multirow[t]{14}{*}{ Bacillariophyceae } & Chaetoceros debilis & Ch48 & 15 & - \\
\hline & Chaetoceros tenuissimus & $2-6$ & 15 & + \\
\hline & Chaetoceros salsugineum & $\mathrm{Ch} 42$ & 15 & - \\
\hline & Chaetoceros socialis f. radians & $\mathrm{L}-4$ & 15 & - \\
\hline & Chaetoceros cf. affinis & Chae5 & 15 & - \\
\hline & Chaetoceros lorenzianus & ItDia-51 & 15 & - \\
\hline & Chaetoceros sp. & IT07-C11 & 15 & - \\
\hline & Chaetoceros cf. pseudocurvisetus & IT07-C37 & 15 & - \\
\hline & Detonula pumila & ItDia-14 & 15 & - \\
\hline & Ditylum brightwellii & ItDia-21 & 15 & - \\
\hline & Eucampia zodiacus & EzB & 15 & - \\
\hline & Rhizosolenia setigera & $\begin{array}{l}L Z D \\
\mathrm{~S} 2\end{array}$ & 15 & - \\
\hline & Skeletonema sp. & ItDia-SK4 & 15 & - \\
\hline & Stephanopyxis sp. & ItDia-Stp8 & 15 & - \\
\hline Eustigmatophyceae & Nannochloropsis sp. & SFBB & 20 & - \\
\hline Cryptophyceae & Teleaulax amphioxeia & Hama3 & 20 & - \\
\hline \multirow[t]{7}{*}{ Dinophyceae } & Alexandrium catenella & ACNG & 20 & - \\
\hline & Gymnodinium catenatum & GC27-1 & 20 & - \\
\hline & Heterocapsa circularisquama & HU9433-P & 20 & - \\
\hline & Heterocapsa triquetra & Ht & 20 & - \\
\hline & Kalenia mikimotoi & $\mathrm{GmIH}$ & 20 & - \\
\hline & Prorocentrum micans & $\mathrm{M}$ & 20 & - \\
\hline & Scrippsiella sp. & SCKR & 20 & - \\
\hline \multirow[t]{5}{*}{ Raphidophyceae } & Chattonella antiqua & CaAR & 20 & - \\
\hline & Chattonella marina & CMKG-1 & 20 & - \\
\hline & Chattonella ovata & $\mathrm{CoV}$ & 20 & - \\
\hline & Fibrocapsa japonica & F96 & 20 & - \\
\hline & Heterosigma akashiwo & H93616 & 20 & - \\
\hline
\end{tabular}

v/v; multiplicity of virus infection, 3.2). As the control, a $C$. tenuissimus culture was inoculated with autoclaved culture medium SWM3. An aliquot of cell suspension was sampled at $48 \mathrm{~h}$ pi. C. tenuissimus cells were harvested by centrifugation at $860 \times g$ at $4{ }^{\circ} \mathrm{C}$ for 10 min and fixed with $1 \%$ glutaraldehyde in SWM3 for $4 \mathrm{~h}$ at $4^{\circ} \mathrm{C}$. The cell pellets were post-fixed for $3 \mathrm{~h}$ in $2 \%$ osmic acid in $0.1 \mathrm{M}$ phosphate buffer $(\mathrm{pH} 7.2$ to 7.4), dehydrated in a graded ethanol series (50 to $100 \%$ ) and embedded in Quetol 812 resin (Nisshin EM). Ultra-thin sections were stained with $4 \%$ uranyl acetate and $3 \%$ lead citrate and observed at $80 \mathrm{kV}$ using a JEOL JEM-1010 transmission electron microscope. CtenDNAV06 particles negatively stained with uranyl acetate were also observed using transmission electron microscopy (TEM). Briefly, a drop of virus lysate was mounted on a grid (No. 780111630; JEOL Datum) for $30 \mathrm{~s}$, and excess water was removed using filter paper (No. 1; TOYO). Then, $4 \%$ uranyl acetate was applied for $10 \mathrm{~s}$, and excess dye was removed using filter paper. After the grid was dried in a desiccator for $>12 \mathrm{~h}$, negatively stained CtenDNAV particles were observed using TEM at $80 \mathrm{kV}$. Particle diameters were estimated using the negatively stained images.
Thermal stability. An exponentially growing culture of Chaetoceros tenuissimus 2-6 was inoculated with CtenDNAV06 and incubated for $4 \mathrm{~d}$. The lysate was passed through a $0.2 \mu \mathrm{m}$ polycarbonate membrane filter (Nuclepore) to remove cellular debris. The titre of the resultant fresh lysate was then estimated using the extinction dilution method, and aliquots of the lysate were stored at $4^{\circ} \mathrm{C}$ in the dark. After the initial titration, aliquots were assayed $181 \mathrm{~d}$ after storage to determine the stability of the virus.

CtenDNAV nucleic acids. Nucleic acids were extracted from the viral pellet using the DNeasy Plant Mini Kit (Qiagen). Aliquots $(7 \mu \mathrm{l})$ of the nucleic acid solution were digested with RNase A (Nippon Gene) at $0.025 \mu \mathrm{g} \mathrm{l}^{-1}$ at $37^{\circ} \mathrm{C}$ for $1 \mathrm{~h}$ or incubated with DNase I (Takara Bio) at $0.5 \mathrm{U}^{-1}$ at $37^{\circ} \mathrm{C}$ for $1 \mathrm{~h}$ or with $\mathrm{S} 1$ nuclease (Takara Bio) at $0.7 \mathrm{U} \mathrm{\mu l}^{-1}$ at $23^{\circ} \mathrm{C}$ for $15 \mathrm{~min}$. Nucleic acid extracts kept on ice without treatment served as controls. The prepared nucleic acid samples were electrophoresed in agarose gels $(1.5 \%$; SeaKem Gold Agarose; BMA) at $50 \mathrm{~V}$ for $1 \mathrm{~h}$. Nucleic acids were visualised using SYBR-Gold staining (Molecular Probes).

Genome sequencing. Sequencing of the viral genome was performed as follows. For constructing 
cDNAs, the purified DNA was treated with a cDNA synthesis kit (MMLV version; Takara) using random primers according to the manufacturer's recommendations. The 5 '-end of the resultant double-stranded DNA (dsDNA) fragments was phosphorylated using T4 polynucleotide kinase (Takara). The resultant cDNA fragments were electrophoresed on an agarose gel, and 1.0 to $1.5 \mathrm{~kb}$ fragments were extracted and ligated into the HincII-cleaved and dephosphorylated pUC118 plasmid vector (Takara). The ligated dsDNA fragments were transformed into Escherichia coli DH10B competent cells (Invitrogen) and sequenced using the dideoxy method on an ABI 3730xl DNA Analyzer (Applied Biosystems). The resultant fragment sequences were reassembled using PGA (CAP4) Ver. 2.6.2 (Paracel).

The S1 nuclease-resistant fragment $(\sim 1 \mathrm{kbp})$ was excised from the gel using Quantum Prep Freeze 'N Squeeze DNA Gel Extraction Spin Columns (Bio-Rad Laboratories), purified using phenol-chloroform extraction and dissolved in ultrapure water. It was then blunt ended, phosphorylated using a Mighty Cloning Kit (Blunt End) (Takara Bio) and ligated into the HincII-cleaved and dephosphorylated pUC118 plasmid vector (Takara). It was sequenced using the dideoxy method on an ABI PRISM 3100 DNA Analyzer (Applied Biosystems).

Southern blot analysis was conducted to distinguish the viral (+) and complementary (-) strand of the single-stranded region of the viral genomic DNA. On the basis of the predicted sequence, digoxigenin-labelled RNA probes specific for either the viral or complementary strand were transcribed from the constructed plasmid with T7 RNA polymerase or T3 RNA polymerase, respectively, according to the manufacturer's protocols (Roche). The nucleotide sequence of the ssDNA region of the CtenDNAV genome was determined by Southern dot-blot analysis using the probes according to a previously reported method (Mizumoto et al. 2007). The signals were detected with a luminescence image analyser (LAS-3000 mini; Fuji Photo Film).

Putative open reading frames (ORFs) were identified using the ORF Finder (www.ncbi.nlm.nih.gov/gorf/ gorf.html). Automated comparisons were conducted comparing the CtenDNAV sequence using the BLAST program (Basic Local Alignment Research Tool; http:// blast.ncbi.nlm.nih.gov/blast.cgi) to genetic databases.

PCR experiment. To confirm whether the viral genome includes a covalently closed circular DNA, 4 primers were designed based on its nucleotide sequence; CtenDV_1 (5'- GTC AAG TCA TTC AAC CAT AGT C -3'), CtenDV_2 (5'- GAC TAT GGT TGA ATG ACT TGA C -3'), CtenDV_3 (5' - CTT TGA CTT CTT ACG ATC CTC -3') and CtenDV_4 (5'- GAG GAT CGT AAG AAG TCA AAG -3') (see Fig. 5). The primer pairs of 'CtenDV_1 and _2' and 'CtenDV_3 and _4' were designed for amplifying the whole genome sequence (estimated size of amplicon is $\sim 5.7 \mathrm{kbp}$ ); 'CtenDV_1 and _4' were designed for amplifying the $\sim 1.8 \mathrm{~kb}$ region, including the $\mathrm{S} 1$ nuclease-resistant fragment to confirm if the circular DNA is closed throughout the dsDNA region, and 'CtenDV_2 and_3' were used for the remaining $\sim 3.9 \mathrm{~kb}$ region.

For amplifying the above-mentioned $\sim 5.7$ and $\sim 3.9 \mathrm{~kb}$ regions, PCR amplification was performed with $20 \mu$ l mixtures containing $\sim 14 \mathrm{ng}$ of template viral DNA, $1 \times$ Blend-Taq buffer (TOYOBO), each deoxynucleoside triphosphate $(200 \mathrm{nM}), 10 \mathrm{pmol}$ of each primer and 1 U of Blend-Taq DNA polymerase using a GeneAmp PCR System 9700 (Applied Biosystems) with the following cycle parameters: 10 rounds of denaturation at $94^{\circ} \mathrm{C}(30 \mathrm{~s})$, annealing at $42^{\circ} \mathrm{C}(30 \mathrm{~s})$ and extension at $72^{\circ} \mathrm{C}(6 \mathrm{~min}) ; 10$ rounds of denaturation at $94^{\circ} \mathrm{C}(30 \mathrm{~s})$, annealing at $47^{\circ} \mathrm{C}(30 \mathrm{~s})$ and extension at $72^{\circ} \mathrm{C}(6 \mathrm{~min})$; and 10 rounds of denaturation at $94^{\circ} \mathrm{C}(30 \mathrm{~s})$, annealing at $52^{\circ} \mathrm{C}(30 \mathrm{~s})$ and extension at $72^{\circ} \mathrm{C}(6 \mathrm{~min})$. For amplifying the $\sim 1.8 \mathrm{~kb}$ region using 'CtenDV_1 and_4', PCR amplification was performed with the same mixture conditions with the following cycle parameters: 30 rounds of denaturation at $94^{\circ} \mathrm{C}$ (30 s), annealing at $52^{\circ} \mathrm{C}(30 \mathrm{~s})$ and extension at $72^{\circ} \mathrm{C}(1.5 \mathrm{~min})$. The PCR products were electrophoresed in $1 \%(\mathrm{w} / \mathrm{v})$ agarose ME gels (Wako Pure Chemical Industries), and nucleic acids were visualised by ethidium bromide staining.

Growth experiment. An exponentially growing culture of Chaetoceros tenuissimus 2-6 (24 ml) at $25^{\circ} \mathrm{C}$ was inoculated with CtenDNAV06 at a multiplicity of infection of 40. A C. tenuissimus 2-6 culture inoculated with an autoclaved viral suspension served as the control. An aliquot of the cell suspension was sampled from each culture at $0,1,2,3,4,5,6,7$ and $8 \mathrm{~d}$ pi, and the number of host cells and viral infectious units were estimated. This experiment was a single trial. Cell counts were carried out with Fuchs-Rosenthal haemocytometer using optical microscopy (Nikon TE-300), without fixation of the samples. The number of viral infectious units was determined using the extinction dilution method (Suttle 1993). Briefly, the samples used for estimations of the viral infectious units were passed through $0.8 \mu \mathrm{m}$ polycarbonate membrane filters (Nuclepore) to remove cellular debris. These filtrates were diluted with modified SWM3 medium in a series of 10fold dilution steps. Aliquots $(100 \mu \mathrm{l})$ of each dilution were added to 8 wells in cell-culture plates with 96 flat-bottom wells and mixed with $150 \mu$ of exponentially growing culture of host algae. The cell culture plates were incubated at $15^{\circ} \mathrm{C}$ under a $12 \mathrm{~h}$ light: $12 \mathrm{~h}$ dark cycle of 130 to $150 \mu \mathrm{mol}$ photons $\mathrm{m}^{-2} \mathrm{~s}^{-1}$ with cool white fluorescent illumination, and were monitored over $14 \mathrm{~d}$ for the occurrence of culture lysis, using opti- 
cal microscopy (TE-300, Nikon). The culture lysis due to a virus infection was usually observed as almost complete crashes of the host cells in a well. We calculated their abundance from the number of wells in which algal lysis occurred using a BASIC program (Nishihara et al. 1986). The burst size was calculated based on the amount of increased infectious titre per decreased host cell number in the same period.

\section{RESULTS AND DISCUSSION}

\section{Isolation of the viral pathogen}

All established virus isolates retained their lytic activity after filtration through a $0.1 \mu \mathrm{m}$ filter. The lytic activities were serially transferable to exponentially growing Chaetoceros tenuissimus cultures. Cytoplasms and photosynthetic pigments in the virusinfected C. tenuissimus cells were degraded relative to the healthy cells (Fig. 1).

A cross reactivity test between 9 virus clones and 14 Chaetoceros tenuissimus strains showed the intra-species host ranges of these viruses were diverse (Table 2). The virus isolates CtenV02, -03, -04 and -05 had the same host-strain specificity pattern as the previously characterized virus CtenRNAV01 and lysed only the $C$. tenuissimus strains 2-10 and AR07-C01. The specificity patterns of the isolates CtenV07 and -08 were also similar to that of CtenRNAV01, but lysed in addition strain 2-6 and, in the case of CtenV07 also AG07-C03. Another 2 isolates, CtenDNAV06 and CtenV09, showed relatively low strain specificity (Table 2). Among the virus clones isolated, the characteristics of CtenDNAV06 were further examined in the present study.

\section{Host range}

The host range of CtenDNAV06 was tested using 28 phytoplankton strains, including 14 diatom strains. CtenDNAV06 was lytic to its original host strain Chaetoceros tenuissimus 2-6, but not to any other microalgal species tested (Table 3). These results show the high species-specific infection of this virus.

\section{Proteins}

Results from SDS-polyacrylamide gel electrophoresis revealed a single major protein band with a molecular weight of $38.5 \mathrm{kDa}$ (Fig. 2); the pattern was apparently different from that of CtenRNAV, which has 3 major polypeptides of 33.5, 31.5 and $30.0 \mathrm{kDa}$ (Shirai et al. 2008).

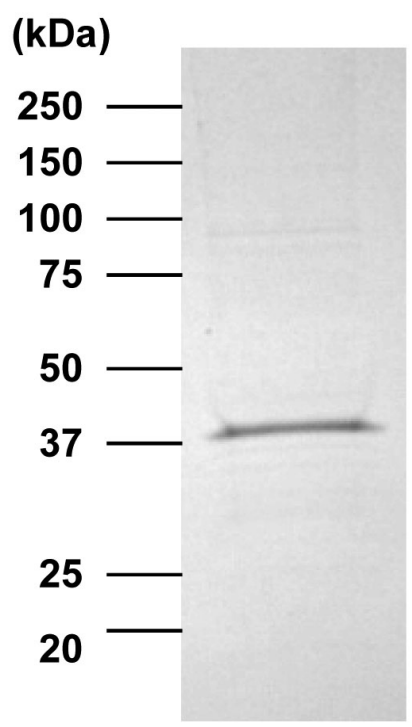

Fig. 2. SDS-polyacrylamide gel of the structural proteins of CtenDNAV. A single major protein band is shown

\section{Morphological features}

Thin sections of healthy Chaetoceros tenuissimus cells showed the cytoplasmic organisation and frustules that are typical of these diatoms (Fig. 3A). In contrast, electron micrographs of thin-sectioned $C$. tenuissimus cells at $48 \mathrm{~h}$ pi with CtenDNAV06 showed the presence of virus-like particles (VLPs) with a mean diameter of $38 \pm 2 \mathrm{~nm}(\mathrm{n}=41)$ randomly assembled in the host nucleus (Fig. 3B,C). VLPs were not found in healthy control cells (Fig. 3A). Further, VLPs were also observed in culture lysates by negative staining electron microscopy. They were hexagonal in outline suggesting icosahedral symmetry, $37 \pm 2 \mathrm{~nm}(\mathrm{n}=30)$ in diameter, lacked a tail and outer membrane and appeared similar to the VLPs observed in the host nucleus (Fig. 3D). Both virion assemblage site and particle diameter were the same as for the ssDNA diatom virus CsalDNAV (Nagasaki et al. 2005). The virion assemblage site of CtenRNAV was the cytoplasm of the infected cell and the particle diameter in the lysate was $31 \mathrm{~nm}$ (Shirai et al. 2008), both characteristics which differ from the present results. Since (1) the algicidal pathogen was transferable to a fresh algal culture, (2) VLPs were observed in the lysed culture and (3) VLPs were not found in healthy cultures, we concluded that the 37 to $38 \mathrm{~nm}$ particles observed within the infected cells and in the algal lysates were most plausibly a virus pathogenic to $C$. tenuissimus. This new virus was designated the $C$. tenuissimus DNA virus (CtenDNAV), after the name of its host species and the genome type (see below).

In addition to the VLPs with diameters of ca. $38 \mathrm{~nm}$, rod-shaped particles $(25 \pm 1 \mathrm{~nm}$ in width, $\mathrm{n}=27)$ were 

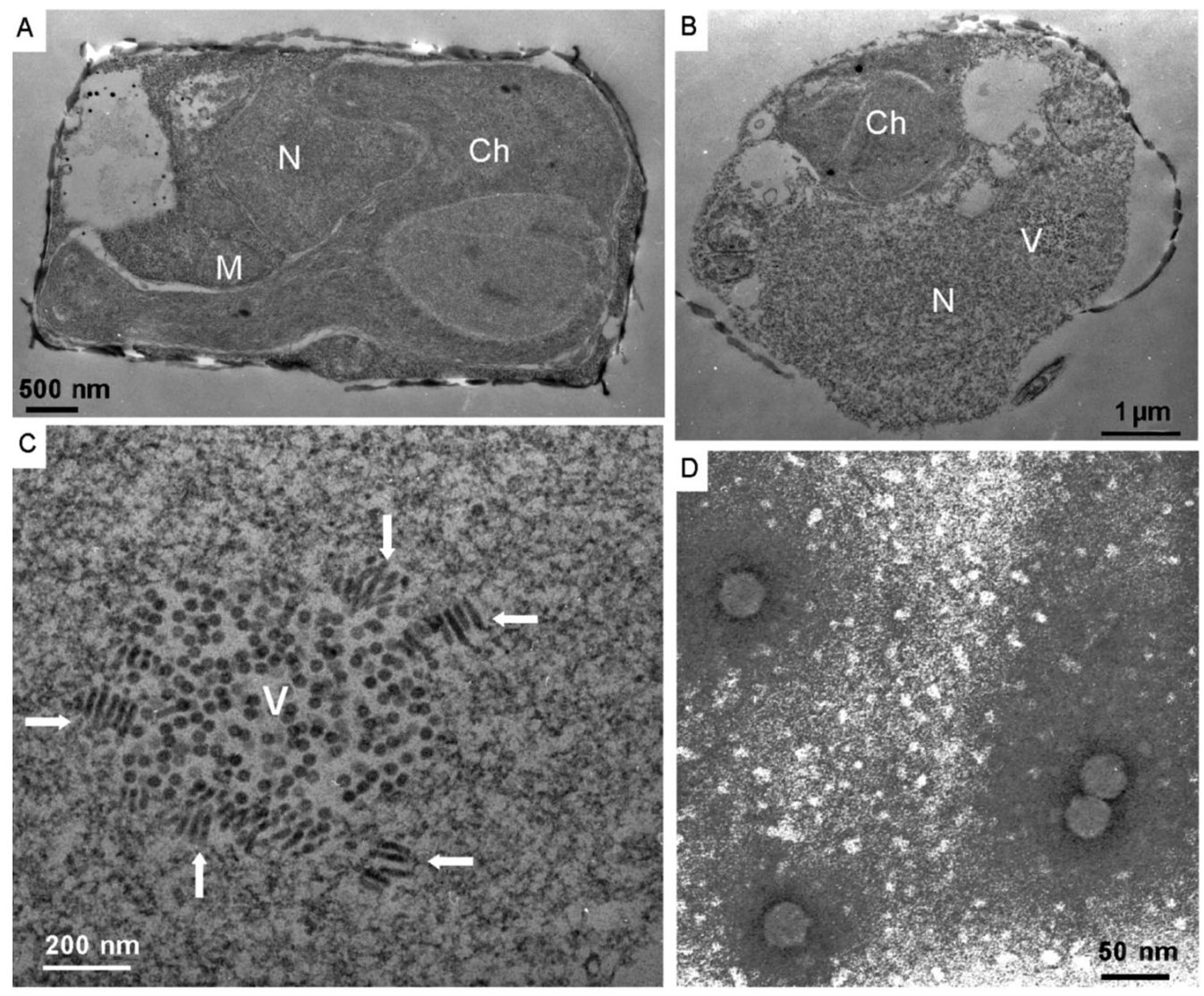

Fig. 3. Transmission electron micrographs of ultra-thin sections of Chaetoceros tenuissimus and negatively stained CtenDNAV particles. (A) Healthy cell. (B, C) Cells infected with CtenDNAV at $48 \mathrm{~h}$ pi: (B) virus-like particles (VLPs) accumulated in the host nucleus and (C) higher magnification of the VLPs and rod-shaped particles (white arrows) in the host nucleus. (D) Negatively stained CtenDNAV particles in the culture lysate. Ch: chloroplast; M: mitochondrion; N: nucleus; V: virus-like particles

also observed in the host nucleus (Fig. 3C). These rodshaped particles were not observed together with the icosahedral VLPs in the negatively stained lysates, suggesting that the concentration of rod-shaped particles might be considerably lower or absent in the lysates. Similar rod-shaped particles have been reported for Chaetoceros cf. wighamii infected with $C$. cf. wighamii nuclear inclusion virus (CwNIV) by Eissler et al. (2009), who suggested that the particles were precursors of mature virions. The alternative hypothesis that the rod-shaped particles represent a co-infecting virus can, however, not be excluded and further analyses will be necessary to clarify the role of these particles in the infected cell nucleus and their relationships to the icosahedral virions.

\section{Thermal stability}

CtenDNAV suspensions containing $5.1 \times 10^{7}$ infectious units $\mathrm{ml}^{-1}$ were stored at $4^{\circ} \mathrm{C}$ in the dark. The titre of the virus suspension after $181 \mathrm{~d}$ of storage was $7.0 \times$ $10^{5}$ infectious units $\mathrm{ml}^{-1}, 1.4 \%$ of the initial titre. The infectivity of this virus was retained after storage at both -20 and $-80^{\circ} \mathrm{C}$ (data not shown). These features are similar to those of other diatom viruses analysed so far (e.g. Shirai et al. 2008, Tomaru et al. 2008).

\section{Genomic analysis}

The intact CtenDNAV06 genome exhibited 2 major bands of nucleic acids, ca. 4.0 and $4.5 \mathrm{kbp}$ (Fig. 4; Lane 1). After heat treatment at $100^{\circ} \mathrm{C}$ for $2 \mathrm{~min}$, the intensity of the larger band was decreased, while the intensity of the smaller was increased (Fig. 4 ; Lane 5). All bands were sensitive to DNase I, but not to RNase A (Fig. 4; Lanes 3 and 4, respectively); therefore, the viral genome is considered to be DNA. In addition, the genome was digested with S1 nuclease; however, a dsDNA of $\sim 0.8 \mathrm{kbp}$ remained undigested (Fig. 4; Lane 2). This result is typical of a covalently closed cir- 


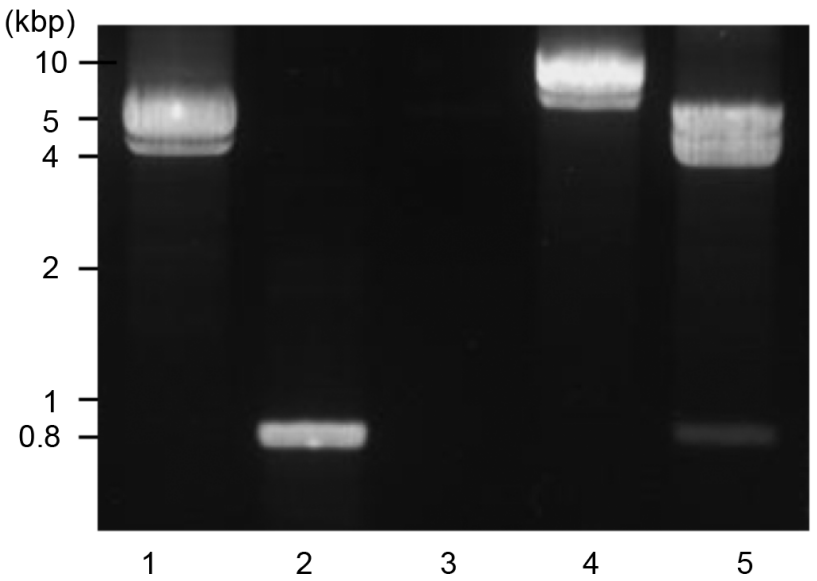

Fig. 4. Nucleic acids of CtenDNAV without treatment (Lane 1), treatment with S1 nuclease (Lane 2), DNase I (Lane 3), RNase A (Lane 4) and $100^{\circ} \mathrm{C}$ for 2 min (Lane 5). Samples were electrophoresed in an agarose gel

cular ssDNA genome containing a partially dsDNA region, as observed for CsalDNAV (Nagasaki et al. 2005).

The following experiments were conducted to confirm the genome structure of CtenDNAV (see 'Materials and methods'). Full sequencing of the CtenDNAV genome revealed that the circular ssDNA and dsDNA regions are 5639 and 875 nt in length, respectively (DNA Data Bank of Japan accession no. AB597949), and then the primer sets shown in Fig. 5 were designed. The PCR experiments resulted in amplification of the expected size fragments: $\sim 5.7 \mathrm{kbp}$ (Fig. 6; Lanes 1 and 2), $\sim 3.9 \mathrm{kbp}$ (Fig. 6; Lane 3) and $\sim 1.8 \mathrm{kbp}$ (Fig. 6; Lane 4). These results indicate the genome includes a covalently closed circular DNA. Based on these data, we concluded that the viral genome consists of a single-strand of covalently closed circular DNA (5639 nt) that is partly doublestranded (875 bp) (Fig. 5).

The genome includes at least 3 major ORFs ( $\geq 300$ amino acids [AA]), designated VP1 to VP3 (Fig. 5). The largest ORF, VP3, with 446 AA showed high similarity with the putative replication-associated protein of CsalDNAV (E-value: $8 \mathrm{e}^{-112}$ ) and CdebDNAV (E-value: $2 \mathrm{e}^{-60}$ ) and low similarity with the replication protein of goose circovirus (E-value: $1 \mathrm{e}^{-5}$ ) and the replicationassociated protein of beak and feather disease virus (Evalue: $1 \mathrm{e}^{-4}$ ), both belonging to ssDNA viruses (family Circoviridae, genus Circovirus; Todd et al. 2000). Other ORFs, VP1 (415 AA) and VP2 (372 AA), have similarities with putative proteins of CsalDNAV, $4 \mathrm{e}^{-17}$ and $3 \mathrm{e}^{-48}$, respectively. Another ORF, VP4 (232AA), is found in the dsDNA region (Fig. 5); however, it is dissimilar to any known proteins. Based on the present results, genome type, structure and sequences, CtenDNAV is considered to be a member of the genus Bacilladnavirus, which is

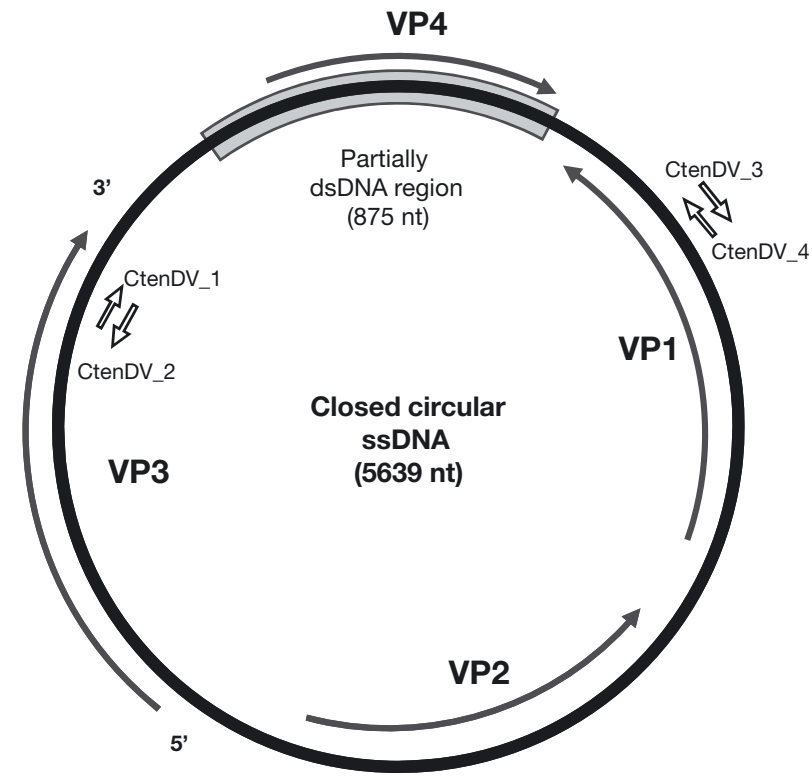

Fig. 5. Schematic genome structure of CtenDNAV. Primers used in the PCR experiments, CtenDV_1 to CtenDV_4 (see 'Materials and methods - PCR experiment' and Fig. 6), are shown as open arrows. Black arrows indicate locations of open reading frames, VP1 to VP4 (see 'Results and discussion-Genomic analysis'), and the gray box is the partially double-stranded DNA (dsDNA) region. ssDNA: singlestranded DNA

a newly accepted genus by the International Committee on Taxonomy of Viruses (ICTV).

\section{Replication}

Chaetoceros tenuissimus grew exponentially for $3 \mathrm{~d}$ in both the virus-inoculated and control cultures, and

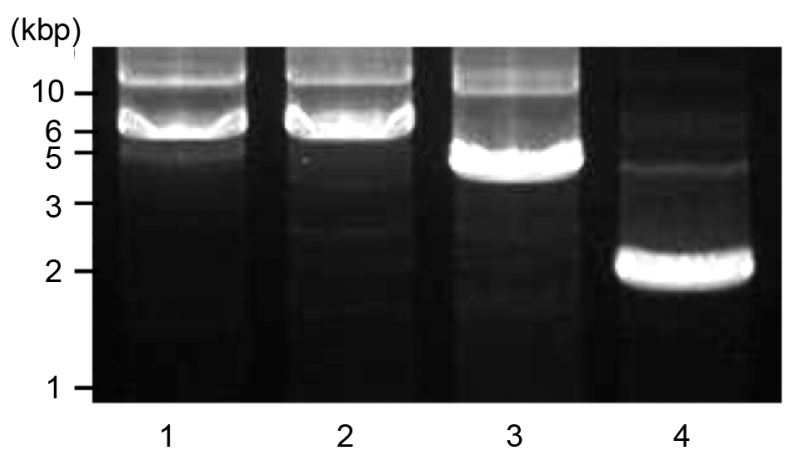

Fig. 6. PCR products amplified with primers (see 'Materials and methods'). Amplicon with CtenDV_1 and _2 (Lane 1), amplicon with CtenDV_3 and _4 (Lane 2), amplicon with CtenDV_2 and_3 (Lane 3), and amplicon with CtenDV_1 and _4 (Lane 4). The most intense bands are the targeted amplicon. The faint bands are probably amplified because of overlaps in the nucleotide sequence 
both cultures reached stationary phase on Day 4 (Fig. 7). The first significant increase in virus abundance was also observed on Day 4 (Fig. 7). A slight increase in viral abundance during exponential host growth or no significant decreases in host cell abundance, and a rapid increase in viral abundance with a concomitant decrease in host cell abundance during stationary phase are commonly observed for Chaetoceros host-virus systems, including CdebDNAV, CsfrRNAV and CtenRNAV (Shirai et al. 2008, Tomaru et al. 2008, 2009b). This may indicate that during exponential growth only a fraction of the host cells are virus sensitive, while during the stationary phase the percentage of virus-sensitive cells quickly increases, and thus that the virus sensitivity of Chaetoceros is related to their physiological conditions. The latent period of CtenDNAV appeared to be $4 \mathrm{~d}$, but it might be shorter if only a small fraction of the cells are virus sensitive during exponential growth.

The average hosts/virus ratio at 4 to $7 \mathrm{~d}$ pi was used to calculate the burst size and was estimated to be $3.2 \times 10^{2}$ infectious units cell $^{-1}$. Considering the adsorption of daughter viruses to uninfected cells or debris in culture, the predicted burst size may be underestimated.

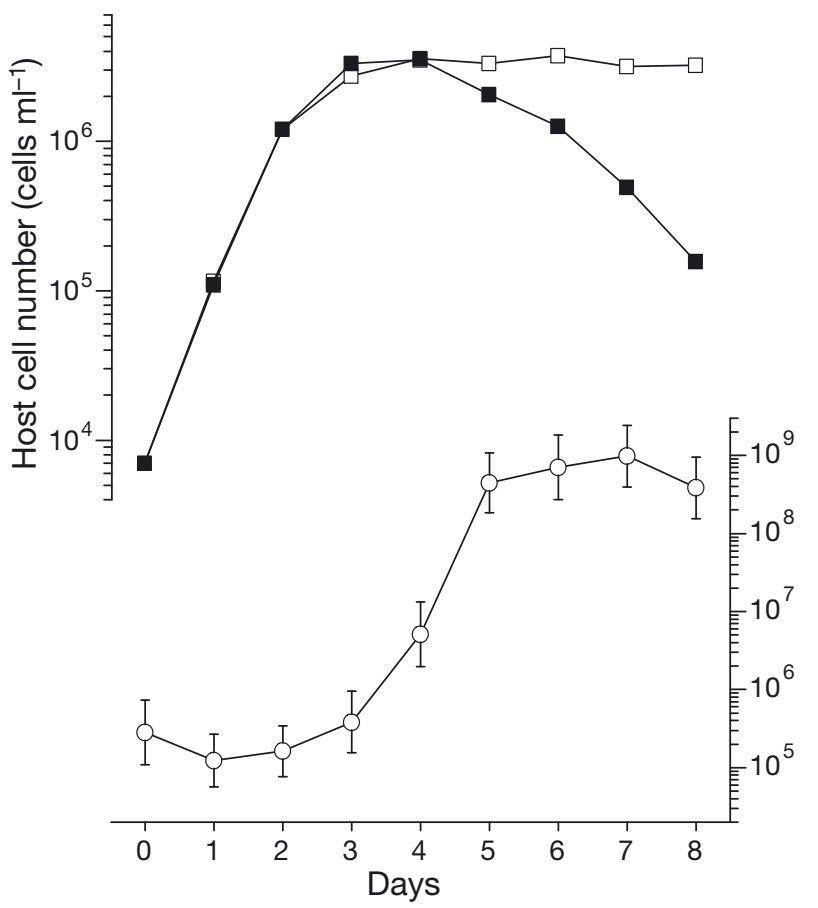

Fig. 7. Chaetoceros tenuissimus. Changes in cell number of $C$. tenuissimus used for growth experiments with (ם) or without virus inoculation $(\square)$ and the virus titre (O). Virus inoculation was performed at $0 \mathrm{~d}$ in an exponentially growing host culture with a multiplicity of infection of 40 . Error bars for virus titres indicate $95 \%$ confidence intervals

\section{Implications}

Blooms of Chaetoceros tenuissimus are often observed in coastal waters off western Japan, and its infectious viruses have been isolated at high frequency during the blooms (Tomaru et al. 2011). These phenomena are similar to those in other microalgal hostvirus systems, e.g. dinoflagellate Heterocapsa circularisquama and its viruses, $\mathrm{HcV}$ and HcDNAV (Tomaru et al. 2009a), and there should be an ecological relationship in each host-virus system in natural environments. One interesting finding of the present study is that viruses with 2 different genome types infect a single host species, C. tenuissimus. Although field surveys revealed that the viruses infecting $C$. tenuissimus specifically increase and coexist with the host populations during the bloom periods (Tomaru et al. 2011), how DNA and RNA viruses affect host dynamics is not understood. In future studies, the host-virus systems established in the current study may be useful to elucidate how each virus species dominates, survives, competes and sustains a symbiotic relationship with the host population in nature and to investigate differences in infection strategies of the 2 viruses and the physiological response of the host to these viral attacks.

Acknowledgements. The present study was supported by Grants-in-Aid for Young Scientists (A) (22688016) from the Ministry of Education, Science and Culture of Japan. We thank N. Fujii (Fukuoka Fisheries and Marine Technology Research Center) for providing water and sediment samples.

\section{LITERATURE CITED}

Bettarel Y, Kan J, Wang K, Williamson KE and others (2005) Isolation and preliminary characterisation of a small nuclear inclusion virus infecting the diatom Chaetoceros cf. gracilis. Aquat Microb Ecol 40:103-114

> Chen LCM, Edelstein T, McLachlan J (1969) Bonnemaisonia hamifera Hariot in nature and in culture. J Phycol 5: 211-220

Eissler Y, Wang K, Chen F, Wommack E, Coats W (2009) Ultrastructural characterization of the lytic cycle of an intranuclear virus infecting the diatom Chaetoceros cf. wighamii (Bacillariophyceae) from Chesapeake Bay, USA. J Phycol 45:787-797

Itoh K, Imai I (1987) Rafido so (Raphidophyceae). In: Japan Fisheries Resource Conservation Association (ed) A guide for studies of red tide organisms. Shuwa, Tokyo, p 122-130 (in Japanese)

>izumoto H, Tomaru Y, Takao Y, Shirai Y, Nagasaki K (2007) Intraspecies host specificity of a single-stranded RNA virus infecting a marine photosynthetic protist is determined at the early steps of infection. J Virol 81:1372-1378

- Nagasaki K, Tomaru Y, Katanozaka N, Shirai Y, Nishida K, Itakura S, Yamaguchi M (2004) Isolation and characterization of a novel single-stranded RNA virus infecting the bloom-forming diatom Rhizosolenia setigera. Appl Environ Microbiol 70:704-711 
Nagasaki K, Tomaru Y, Takao Y, Nishida K, Shirai Y, Suzuki H, Nagumo T (2005) Previously unknown virus infects marine diatom. Appl Environ Microbiol 71:3528-3535

Nishihara T, Kurano N, Shinoda S (1986) Calculation of most probable number for enumeration of bacteria on microcomputer. Jpn J Toxicol Environ Health 32:226-228 (in Japanese with English abstract)

Shirai Y, Tomaru Y, Takao Y, Suzuki H, Nagumo T, Nagasaki $K$ (2008) Isolation and characterization of a singlestranded RNA virus infecting the marine planktonic diatom Chaetoceros tenuissimus Meunier. Appl Environ Microbiol 74:4022-4027

Suttle CA (1993) Enumeration and isolation of viruses. In: Kemp PF, Sherr E, Cole JJ (eds) Handbook of methods in aquatic microbial ecology. Lewis Publishers, Boca Raton, FL, p 121-134

Todd D, McNulty MS, Mankertz A, Lukert P, Randels JW, Dale JL (2000) Family Circoviridae. In: Van Regenmortel MHV, Fauquet CM, Bishop DHL, Carsten EB and others (eds) Virus taxonomy, classification, and nomenclature of viruses, 7th report. Academic Press, San Diego, CA, p 299-303

Editorial responsibility: Gunnar Bratbak, Bergen, Norway
Tomaru Y, Tarutani K, Yamaguchi M, Nagasaki K (2004) Quantitative and qualitative impacts of viral infection on Heterosigma akashiwo (Raphidophyceae) population during a bloom in Hiroshima Bay, Japan. Aquat Microb Ecol 34:227-238

Tomaru Y, Shirai Y, Suzuki H, Nagumo T, Nagasaki K (2008) Isolation and characterization of a new singlestranded DNA virus infecting the cosmopolitan marine diatom Chaetoceros debilis. Aquat Microb Ecol 50: 103-112

Tomaru Y, Mizumoto H, Takao Y, Nagasaki K (2009a) Cooccurrence of DNA- and RNA-viruses infecting the bloomforming dinoflagellate, Heterocapsa circularisquama, on the Japan coast. Plankton Benthos Res 4:129-134

Tomaru Y, Takao Y, Suzuki H, Nagumo T, Nagasaki K (2009b) Isolation and characterization of a single-stranded RNA virus infecting the bloom forming diatom Chaetoceros socialis. Appl Environ Microbiol 75:2375-2381

Tomaru Y, Fujii N, Oda S, Toyoda K, Nagasaki K (2011) Dynamics of diatom viruses on the western coast of Japan. Aquat Microb Ecol 63:223-230

Submitted: January 24, 2011; Accepted: May 9, 2011 Proofs received from author(s): August 11, 2011 